\title{
NASAL ENDOSCOPY PROSPECTSIN EXPERIMENTAL RHINOLOGY: SOME ASPECTS OF ENISAMIUM IODIDE NASAL SPRAY EFFECTIVENESS IN RHINOSINUSITIS
}

\author{
${ }^{I}$ Department of Clinical Pharmacology and Clinical Pharmacy, \\ National University of Pharmacy, Kharkiv, Ukraine \\ ${ }^{2}$ Non-profitMunicipal Enterprise «City Clinical Hospital №30» \\ of Kharkiv City Council, Kharkiv, Ukraine
}

Acute rhinosinusitis (ARS) symptoms are presented of two or more symptoms like nasal blockage/obstruction/congestion or nasal discharge (anterior/posterior nasal drip) and facial pain/pressure or reduction/loss of smell or cough in daytime and night-time (in children), with sudden onset of symptoms and duration, not more than 12 weeks [1]. ARS treatment and prevention is connected to the rational choice of drug dosage form, which will provide the therapeutic effect and the safety of a drug substance or a drug substance complex [14]. Anti-exudative action of Enisamium Iodide (EI) is the well-known advantage and used for treatment and prevention of acute respiratory viral infections with significantly increase patients' quality of life by nasal congestion relief, which is one of the major symptoms of ARS $[1,4]$. Farmak JSC (Ukraine) has developed a new nasal spray with Enisamium Iodide aqueous solution (N-methyl-4benzylcarbamidopyridinium Iodide) - original dosage form of a well-known pharmaceutical substance.

The anti-inflammatory action of Enisamium Iodide (EI) has been proved in the preclinical studies [5-7]. Nasal spray dosage form potentially can have high drug effectiveness for ARS treatment by a direct positive effect on the inflammation and swelling into the sinus ostium. Nevertheless, for drug effectiveness evaluation can be required nasal endoscopy (NE)as clear evaluation criteria $[1,8-10]$, us the most informative visual methods with high reliability, safety and result saving via photo and video equipment. Therefore, researchers could be used NE in experimental rhinology as a method of direct visualization for confirmation of induced pathology as well as a method for evaluation of the effectiveness of test drugs [10].

Aim: To substantiate the effectiveness of EI (nasal spray) $10 \mathrm{mg} / \mathrm{mL}$ on the maxillary sinus ostium state via NE in rabbits with experimental rhinosinusitis (ERS) was our comparative study aim.

\section{Material and methods}

To achieve this study aimed, we developed the study design, which is shown in Fig. 1. As test object, we have chosen a new nasal spray with an aqueous solution of EI (Farmak JSC, Ukraine) at concentration $10 \mathrm{mg} / \mathrm{mL}$ according to results of the previous stage of experimental study [5-7]. We administered nasal spray at $0.1 \mathrm{~mL}$ intranasally (i.n.) (Tabl. 1). This dose has corresponded to the dose of $0.03 \mathrm{~mL} / \mathrm{kg}$ by average weight of a rabbit at the study beginning (around $3.0 \mathrm{~kg}$ ). This dose corresponds to $0.6 \mathrm{~mL}$ for a human, i.e. $0.2 \mathrm{~mL}$ (twice pressing of the dosing valve) per 3 times a day in an unchanged state into the right rabbit nasal passage using Biohit Proline fixed volume pipettor $200 \mu \mathrm{l}$ with Biohite pipettor tips [11]. The dose has been calculated according to the FDA recommendations on 
dose extrapolation [12]. In the intact control and control pathology groups was used $0.9 \%$ saline in an equivalent dose and route of administration (Tabl. 1).

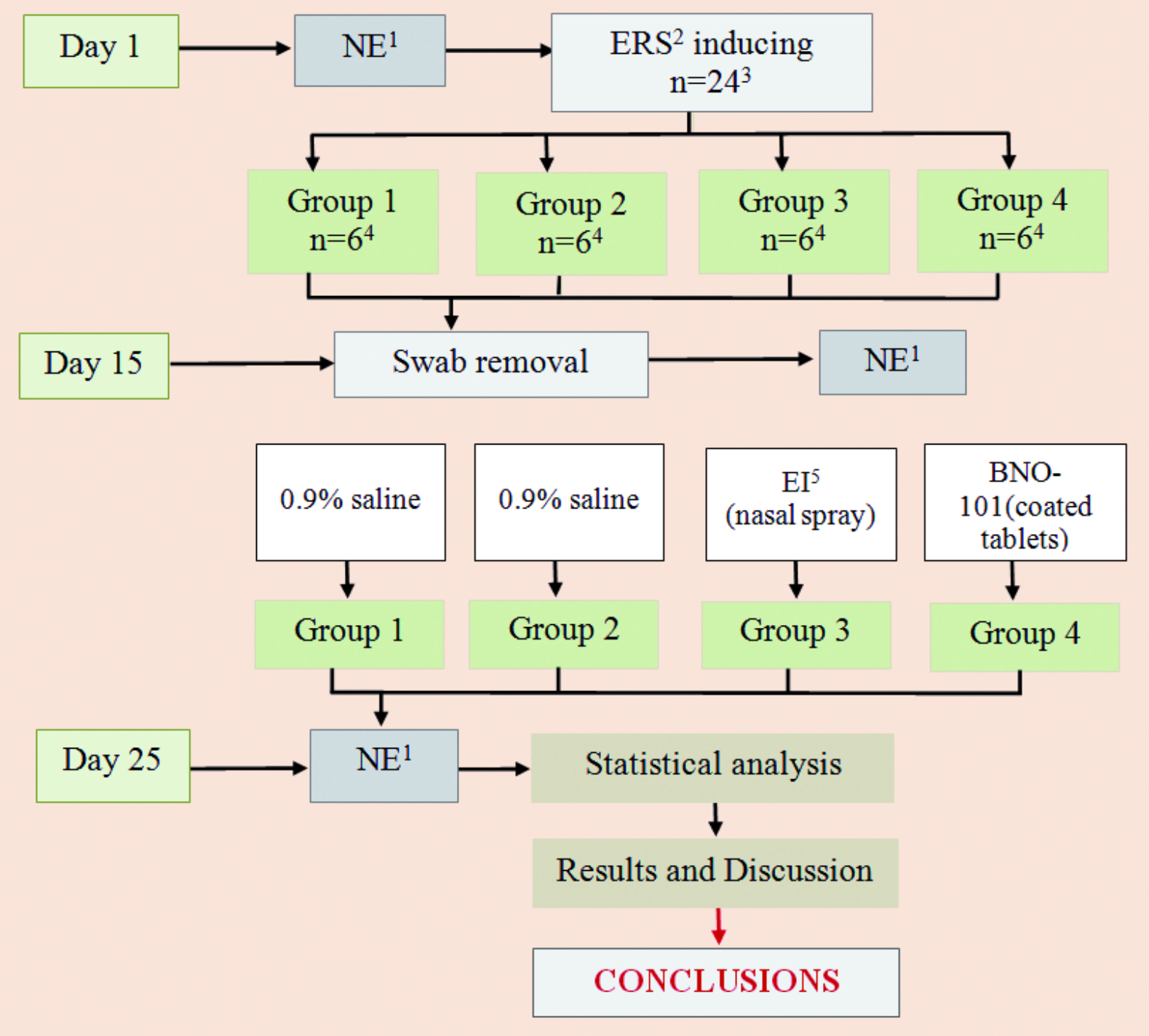

Fig. 1. Preclinical study design «The effectiveness of the test objects on the maxillary sinus ostium via $\mathrm{NE}^{1}$ in rabbits with $\mathrm{ERS}^{2} »$ :

${ }^{1} \mathrm{NE}$, nasal endoscopy;

${ }^{2}$ ERS, experimental rhinosinusitis;

${ }^{3} \mathrm{n}$, total number of the experimental animals;

${ }^{4} \mathrm{n}$, number of the experimental animals in each groups;

${ }^{5}$ EI, Enisamiun Iodide (nasal spray) $10 \mathrm{mg} / \mathrm{mL}$;

${ }^{6} 25 \mathrm{mg} / \mathrm{kg}, \mathrm{ED}_{50}$ for the anti-inflammatory activity.

BNO-101 by trade name Sinupret ${ }^{\circledR}$ («Bionorica SE», Germany) in coated tablets for oral use containing $78 \mathrm{mg}$ of native herbal extract in each tablet (Rumex acetosa, Sambucus nigra, Primula veris, Verbena Officinalis, Gentiana lutea) was the reference drug. BNO-101 was administered at dose of $25 \mathrm{mg} / \mathrm{kg}$ to rabbits orally (intragastrically) as a water suspension via a special catheter with an elastic cannula (Tabl. 1). Under FDA recommendations [12] this dose has corresponded to the dose of $480 \mathrm{mg}$ for human or 6 tablets, i.e. 2 tablets 3 times a day that is equal to the recommended dosage regime indicated in the drug label [13]. 
To induce ERS we used twenty-four white New Zealand rabbits of both sexes aged around $90-110$ days weighing $2.5-3 \mathrm{~kg}$ by tamponade of the right halves of the nasal cavity under general anesthesia with Ketamine/Xylazine $(35 / 5 \mathrm{mg} / \mathrm{kg}$, intramuscularly [14] which is a well-known model of RS in experimental rhinology $[15,16]$ at the first day. After $15^{\text {th }}$ day, sponges were removed and during the further 10 days, study objects were administered at the respective doses (Table 1).

We used NE of the right halves of the nasal cavity under general anesthesia [14] for ERS manifestation in all study stages (Fig. 1) by Karl Storz rhinoscopes (Germany). The pictures were digitally captured and examined to reveal the pathological changes of the maxillary sinus ostium. The semi-quantitative assessment was used to assure of the study re- sults objectivity. A range of total scores was assessed which represents the maxillary sinus ostium damage (Table 2). At the end of the study, the animals were euthanized under general anesthesia [14] in compliance with bioethical standards of conducting experiments with laboratory animals [17].

The test animals were kept in the Vivarium of the Central Research Laboratory, National University of Pharmacy (Kharkiv, Ukraine) following the sanitary standards and the required diet. All researches were conducted in accordance with the Directive 2010/63/EU on compliance with the laws, directives and administrative regulations of the EU countries on the protection of animals used for scientific purposes [18]. The Bioethics Commission of the National University of Pharmacy (Kharkiv, Ukraine) approved study design (Protocol No3 of 15 March 2017).

Table 1

The distribution of experimental animals $(1 n=24)$

\begin{tabular}{|c|l|c|c|c|}
\hline \multicolumn{2}{|c|}{ Animal groups } & Study object & $\begin{array}{c}\text { Daily dose, } \\
\text { concentration }\end{array}$ & $\begin{array}{c}\text { Route of } \\
\text { administration }\end{array}$ \\
\hline 1 & Intact control group $\left(\mathrm{n}^{2}=6\right)$ & $0.9 \%$ saline & $0.1 \mathrm{~mL}$ & Intranasally \\
\hline 2 & Control pathology group $\left(\mathrm{n}^{2}=6\right)$ & $0.9 \%$ saline & $0.1 \mathrm{~mL}$ & Intranasally \\
\hline 3 & Enisamium Iodide treated group $\left(\mathrm{n}^{2}=6\right)$ & $\begin{array}{c}\text { Enisamium Iodide } \\
\text { (nasal spray) }\end{array}$ & $0.1 \mathrm{~mL}$ & Intranasally \\
\hline 4 & BNO-101 treated group $\left(\mathrm{n}^{2}=6\right)$ & $\begin{array}{c}\text { BNO-101 } \\
\text { (coated tablets) }\end{array}$ & $25 \mathrm{mg} / \mathrm{kg}^{3}$ & Intragastrically \\
\hline
\end{tabular}

${ }^{1} \mathrm{n}$, total number of the experimental animals;

${ }^{2} \mathrm{n}$, number of the experimental animals in each groups;

${ }^{3} 25 \mathrm{mg} / \mathrm{kg}, \mathrm{ED}_{50}$ for the anti-inflammatory activity.

Table 2

The scale for endoscopic assessment of the experimental rhinosinusitis severity via the maxillary sinus ostium state in rabbits

\begin{tabular}{|c|c|c|c|}
\hline \multicolumn{3}{|c|}{ The maxillary sinus ostium state } & Points \\
\hline \multicolumn{3}{|c|}{ no swelling, the maxillary sinus ostium is functioning } & 0 \\
\hline \multicolumn{3}{|c|}{ insignificant swelling, the maxillary sinus ostium is functioning partially } & 1 \\
\hline \multicolumn{3}{|c|}{ significant swelling, the maxillary sinus ostium is not functioning (sinus ostium is blocked) } & 2 \\
\hline \multicolumn{4}{|c|}{ The severity of the experimental rhinosinusitis manifestations } \\
\hline Severity degree & The total score & Severity degree & The total score \\
\hline No changes (physiological state) & $0-0.4$ & Moderate & $1.1-1.5$ \\
\hline Mild & $0.5-1.0$ & Severe & $1.6-2.0$ \\
\hline
\end{tabular}




\section{Statistical Analysis}

Statistical analysis of the results was performed using Kruskal-Wallis one-way analysis of variance and Mann-Whitney $U$ test for a posteriori pair wise comparisons $[19,20]$. Uti-

\section{Results and Discussion \\ Intact control group}

NE of the right half of the nasal cavity in the intact control group did not reveal pathological changes of anatomical structures including maxillary sinus ostium. On the $15^{\text {th }}$ and $25^{\text {th }}$ days of the study, swelling of the maxillary sinus ostium was not detected and the normal lized computer software included IBM SPSS Statistics v. 22 (IBM Corp., USA) and MS Excel 2016 (Microsoft Corp., USA). The level of statistical significance was considered as $\mathrm{p}<0.05$.

function of the maxillary sinus ostium was preserved in all animals (Fig. 2).

The semi-quantitative assessment of rabbit nasal cavity with ERS is presented in Table 3. The total scores calculated for the intact group was $0(0 \div 0)$ at the first and the second stages of the study which corresponds to the physiological state (Table 2).

Table 3

The semi-quantitative assessment of the maxillary sinus ostium state in rabbits with experimental rhinosinusitis under Enisamium Iodide $10 \mathrm{mg} / \mathrm{mL}$ (nasal spray) and BNO-101 influence according to the endoscopic evaluation $\left(\mathrm{n}^{1}=24\right)$

\begin{tabular}{|c|c|c|c|c|c|}
\hline \multirow{4}{*}{\multicolumn{2}{|c|}{ Experimental groups }} & \multicolumn{3}{|c|}{ The number/relative percentage } & \multirow{4}{*}{$\begin{array}{c}\text { The total score } \\
\text { (median; } \min \div \max \text { ) }\end{array}$} \\
\hline & & \multicolumn{3}{|c|}{ The state of the maxillary sinus ostium } & \\
\hline & & \multicolumn{3}{|c|}{ points } & \\
\hline & & 0 & 1 & 2 & \\
\hline \multicolumn{6}{|c|}{$15^{\text {th }}$ day of the study } \\
\hline 1 & Intact control group $\left(\mathrm{n}^{2}=6\right)$ & $6 / 100 \%$ & 0 & 0 & $\begin{array}{c}0 \\
(0 \div 0)\end{array}$ \\
\hline 2 & Control pathology group $\left(n^{2}=6\right)$ & 0 & 0 & $6 / 100 \%$ & $\begin{array}{c}2.0^{3} \\
(2.0 \div 2.0)\end{array}$ \\
\hline 3 & Enisamium Iodide treated group $\left(\mathrm{n}^{2}=6\right)$ & 0 & $2 / 33 \%$ & $4 / 67 \%$ & $\begin{array}{c}2.0^{3} \\
(1.0 \div 2.0)\end{array}$ \\
\hline 4 & BNO-101 treated group $\left(n^{2}=6\right)$ & 0 & $2 / 33 \%$ & $4 / 67 \%$ & $\begin{array}{c}2.0^{3} \\
(1.0 \div 2.0)\end{array}$ \\
\hline \multicolumn{6}{|c|}{$25^{\text {th }}$ day of the study } \\
\hline 1 & $\begin{array}{l}\text { Intact control group } \\
\left(\mathrm{n}^{2}=6\right)\end{array}$ & $6 / 100 \%$ & 0 & 0 & $\begin{array}{c}0 \\
(0 \div 0)\end{array}$ \\
\hline 2 & Control pathology group $\left(n^{2}=6\right)$ & 0 & $2 / 33 \%$ & $4 / 67 \%$ & $\begin{array}{c}2.0^{3} \\
(1.0 \div 2.0)\end{array}$ \\
\hline 3 & Enisamium Iodide treated group $\left(\mathrm{n}^{2}=6\right)$ & $4 / 67 \%$ & $2 / 33 \%$ & 0 & $\begin{array}{c}0.0^{3,4,5} \\
(0.0 \div 1.0)\end{array}$ \\
\hline 4 & BNO-101 treated group $\left(n^{2}=6\right)$ & 0 & $6 / 100 \%$ & 0 & $\begin{array}{c}1.0^{3,4} \\
(1.0 \div 1.0)\end{array}$ \\
\hline
\end{tabular}

${ }^{1} \mathrm{n}$, total number of the experimental animals;

${ }^{2} \mathrm{n}$, number of the experimental animals in each group;

3 - differences are significant compared to the intact control group $(\mathrm{p}<0.05)$;

${ }^{4}$ - differences are significant compared to the control pathology group $(\mathrm{p}<0.05)$;

${ }^{5}$ - differences are significant compared to BNO-101 treated group $(\mathrm{p}<0.05)$. 


\section{Control pathology group}

The first NE in the control pathology group we performed on the $15^{\text {th }}$ day for confirmation of ERS after sponge removal. All animals had significant swelling of the maxillary sinus ostium that was narrowed and blocked (Fig. 3).

The second NE we performed on the 25 th day to determine the extent of ERS progression or regression. Most of the animals $(67 \%)$ had significant swelling of the maxillary sinus ostium that was narrowed and did not

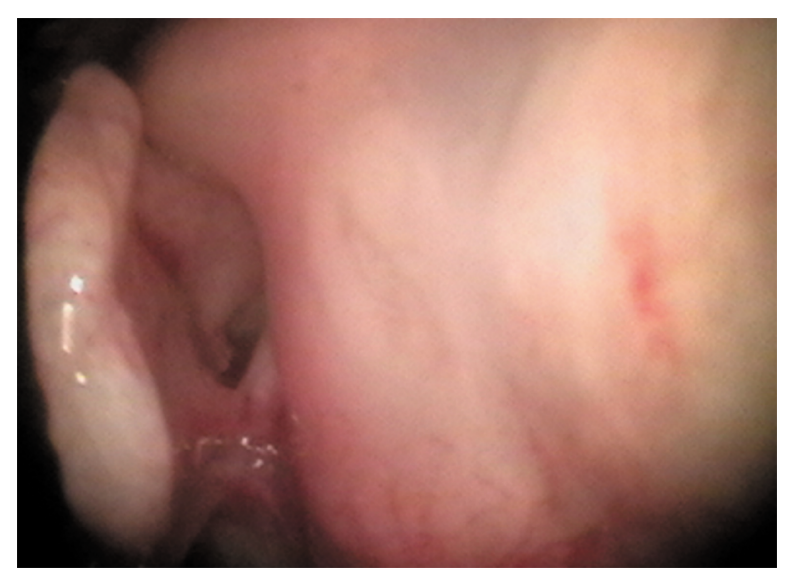

Figure 2 Nasal endoscopy of the intact control group on the $15^{\text {th }}$ day of the study (the right half of the nasal cavity, experimental rhinosinusitis)

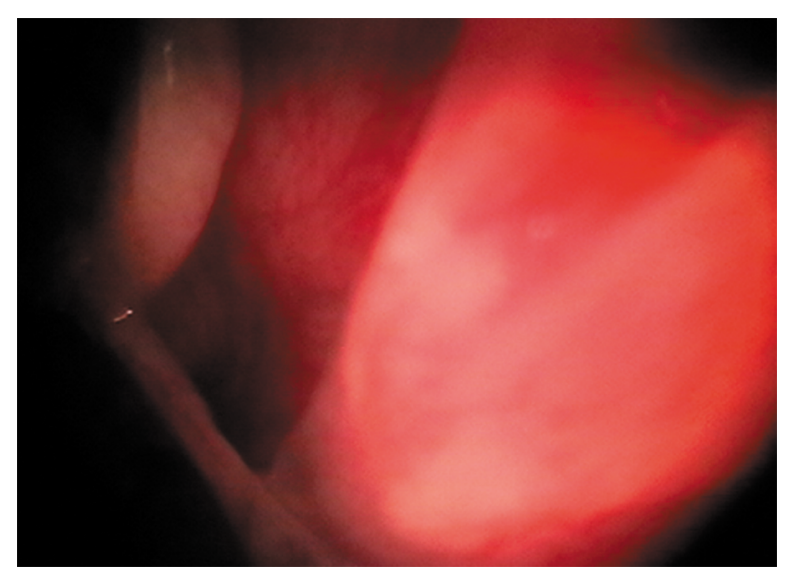

Figure 4A function appropriately, in two rabbits (33\%), the swelling was insignificant and the maxillary hiatus functioned partially.

According to the results of the semiquantitative assessment, the total scores was $2.0(2.0 \div 2.0)$ on the $15^{\text {th }}$ day and $2.0(1.0 \div$ $2.0)$ on $25^{\text {th }}$ day. Which is significantly greater than in the intact control group $(\mathrm{p}<0.05$ vs. intact control group) and could be defined as a severe RS, however with a minimum regression of endoscopic sings on $25^{\text {th }}$ day (Table 2 and 3 ).

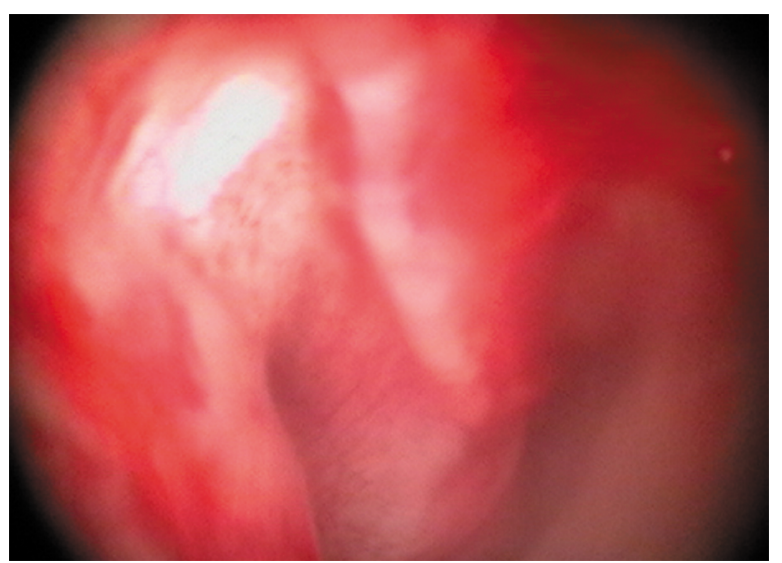

Figure 3 Nasal endoscopy of the control pathology group on the 15th day of the study (the right half of the nasal cavity, experimental rhinosinusitis).

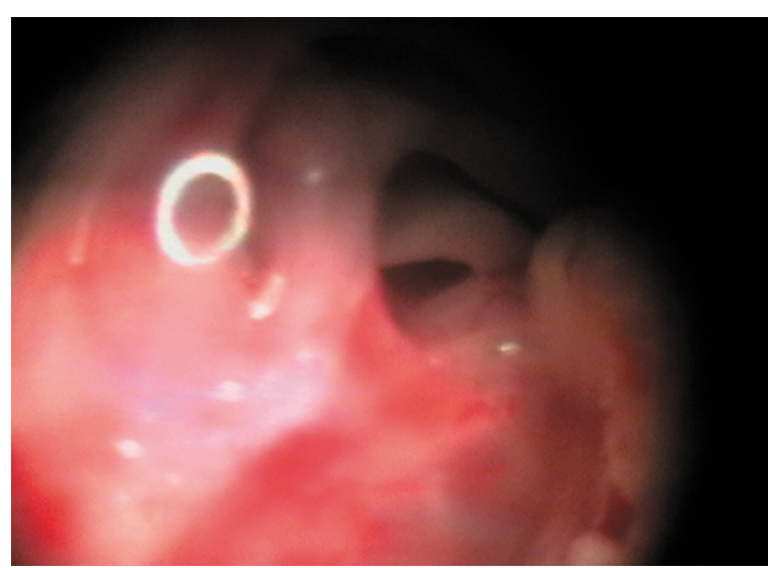

Figure 4B

Figure 4 Nasal endoscopy of EI treated group on the 25th day of the study (the right half of the nasal cavity, experimental rhinosinusitis):

A - insignificant swelling of maxillary sinus ostium, the maxillary sinus ostium functions partially; $\mathrm{B}$ - there is no swelling of the maxillary sinus ostium, the maxillary sinus ostium is functioning. 


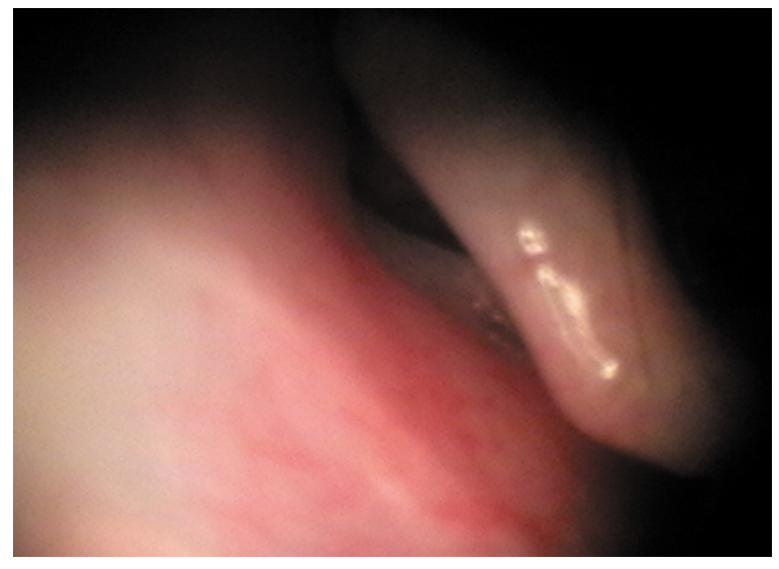

Figure 5 The nasal endoscopy of BNO-101 treated group on the 25 th day of the study (the right half of the nasal cavity, experimental rhinosinusitis).

\section{EI treated group}

On the 15th day by NE results of EI treated group, we identified significant signs of RS manifestation before the treatment has been started - the significant swelling of the maxillary sinus ostium in four rabbits $(67 \%)$ and the maxillary sinus ostium was narrowed and did not function. Other animals (33\%) had insignificant swelling of the maxillary sinus ostium and the maxillary sinus ostium function was partially preserved.

On the 25th day by the second NE results of this group after EI $10 \mathrm{mg} / \mathrm{mL}$ (nasal spray) administration during for 10 days, we identified signs of RS regression. Two rabbits (33\%) had insignificant swelling of the maxillary sinus ostium preserving its partial function while four rabbits $(67 \%)$ did not have swelling and demonstrated the normal function of the maxillary sinus ostium (Fig. 4). These findings generally confirm the regression of ERS caused by EI effect.

The total scores on the $15^{\text {th }}$ day concluded $2.0(1.0 \div 2.0)$ which is significantly greater than in the group of intact animals $(p<0.05$ vs. intact control group) and thus could be referred to severe RS (Table 2 and 3). In contrast, on the $25^{\text {th }}$ day, the total scores was $0.0(0.0 \div 1.0)(\mathrm{p}<0.05$ vs. intact control group, control pathology group and BNO-101 treated group), which corresponds to physiological state (Table 2 and 3 ) and proves the test drug effectiveness.

\section{BNO-101 treated group}

$\mathrm{NE}$ on the 15th day revealed a situation similar to the previous group.NE on the 25th day revealed that all animals had insignificant swelling of the maxillary sinus ostium, which functioned partially (Fig. 5). These findings generally confirm the regression of ERS caused by BNO-101 effect.

The total scores on the $15^{\text {th }}$ day was 2.0 $(1.0 \div 2.0)$, which refers to the control pathology group ( $<<0.05$ vs. intact control group) and confirms the manifestation of severe ERS (Table 2 and 3 ). The total scores has significantly lowered and was $1.0(1.0 \div 1.0)$, which refers to mild ERS (Table 2 and 3 ) and proves the reference drug effectiveness.

It is useful to note that according to the criterion, which was used, BNO-101 had significantly lower activity compared to EI (nasal spray) ( $<<0.05$ vs. BNO-101 treated group). These data present the evidence in favors of the test object and demonstrate its advantage compared to the well-known drug for RS treatment. It can be explained by the difference between their primary pharmacodynamic effects. BNO101 has significant secretolytic activity 15 in contrast to EI, which mostly shows the antiinflammatory effect.

\section{Conclusions}

Nasal endoscopy has prospects in rhinological preclinical studies and can be used as an informative method for induced pathology visualization as well as for the endoscopic evaluation of the treatment effectiveness. Enisamium Iodide (nasal spray) $10 \mathrm{mg} / \mathrm{mL}$, which was using 10 days intranasally, showed a positive effect on ERS regression by endoscopic results. Enisamium Iodide outweighed activity of the reference drug BNO-101 (tablets) by the state of the maxillary sinus ostium (more pronounced anti-exudative effect). Anti-exudative effect of Enisamium Iodide (nasal spray) at intranasal administration has been developed faster than secretolytic effect of BNO-101 at oral administration according to nasal endoscopy. Enisamium Iodide (nasal spray) is a perspective object for further pre-clinical studies and clinical trials aiming to substantiate of its use for the ARS treatment and prevention of its complication as well as its implementation to the clinical practice. 


\section{References}

1. Fokkens WJ, Lund VJ, Hopkins C, Hellings PW, Kern R, Reitsma S, et al. European position paper on rhinosinusitis and nasal polyps 2020. Rhinology. 2020 Feb 20;58 (Suppl S29): 1-464. doi: 10.4193/Rhin20.600.

2. Koch AK, Klose P, Lauche R, Cramer H, Baasch J, Dobos GJ, et al. A Systematic Review of Phytotherapy for Acute Rhinosinusitis. Forsch Komplementmed. 2016; 23(3): 165-9. doi: 10.1159/ 000447467.

3. Chow AW, Benninger MS, Brook I, Brozek JL, Goldstein EJ, Hicks LA, et al. IDSA clinical practice guideline for acute bacterial rhinosinusitis in children and adults. Clin Infect Dis. 2012 Apr; 54(8): e72-e112. doi: 10.1093/cid/cir1043.

4. [Unified clinical protocol for primary, secondary (specialized) and tertiary (highly specialized) care: acute rhinosinusitis]. Order of the Ministry of Health of Ukraine № 85, 11.02.2016. [In Ukrainian] Available from: https://dec.gov.ua/wpcontent/uploads/images/dodatki/2016_85_GRS/ 2016_85_YKPMD_GRS.pdf.

5. Zhulai TS, Zupanets IA, Shebeko SK. [Investigation of dose dependence of anti-exudative action of a new nasal spray with anti-inflammatory properties]. Clinical Pharmacy, 2017; 21(4): 11-7. http://doi.org/10.24959/cphj.17.1446. [Article in Ukrainian].

6. Zhulai TS. Preclinical study of a new nasal spray with anti-inflammatory properties: the effect on the leukotriene-induced inflammation. Clinical pharmacy. 2018; 22(4): 27-33. http://doi.org/ 10.24959/cphj.18.1473.

7. Zhulai T, Shebeko S, Goy A. Perspectives for use of the new nasal spray with anti-inflammatory action in treatment of acute rhinosinusitis. Rhinology. 2018;56(Suppl 27): S585.

8. Cohen-Kerem R, Marshak T, Uri N, Gruber M, Huberfeld O, Paz D, et al. Is Nasal Endoscopy of Diagnostic Value in Chronic Rhinosinusitis Without Nasal Polyps? Ear Nose Throat J. 2019 Sep 23:145561319864578. doi: $10.1177 / 0$ 145561319864578 .

9. Wuister AM, Goto NA, Oostveen EJ, de Jong WU, van der Valk ES, Kaper NM, et al. Nasal endoscopy is recommended for diagnosing adults with chronic rhinosinusitis. Otolaryngol Head Neck Surg. 2014 Mar; 150(3): 359-64. doi: $10.1177 / 0194599813514510$.

10. Colley P, Mace JC, Schaberg MR, Smith TL, Tabaee A. Impact of educational intervention on the interrater agreement of nasal endoscopy interpretation. Laryngoscope. 2015 Oct; 125(10): 2259-65. doi: 10.1002/lary.25240.
11. Turner PV, Pekow C, Vasbinder MA, Brabb T. Administration of substances to laboratory animals: equipment considerations, vehicle selection, and solute preparation. J Am Assoc Lab Anim Sci. 2011 Sep;50(5):614-27.

12. Guidance lor industry. Estimating the Maximum Safe Starting Dose in Initial Clinical Trials lor Therapeutics in Adult Healthy Volunteers. 2005. Available from: https://www.fda.gov/regulatoryinformation/search-fda-guidance-documents/ estimating-maximum-safe-starting-dose-initialclinical-trials-therapeutics-adult-healthy-volunteers.

13. [On state registration (re-registration) of medicinal products (medical immunobiological preparations) and amendments to registration materials. Ministry of Health of Ukraine, Order No. 509 of May 12, 2017]. Available from: http://search.ligazakon.ua/ 1_doc2.nsf/link1/MOZ27507.html. [In Ukrainian].

14. Flecknell PA, editor. Laboratory Animal Anesthesia. $4^{\text {th }}$ ed. Oxford: Academic Press; 2015. 350 p. Available from: http://dx.doi.org/10.1016/C20130-13494-0.

15. Perez AC, Buzatto GP, Dantas I de P, Dorgam JV, Valera FC, Tamashiro E, et al. [Review of experimental models: sinusitis in rabbits]. Braz J Otorhinolaryngol. 2014 Sep-Oct; 80(5): 435-40. doi: 10.1016/j.bjorl.2014.07.011. [Article in Portuguese].

16. Costa HO, Ruschi e Luchi GE, Augusto AG, Castro M, de Souza FC. Comparative study of several sinusitis experimental modeling techniques in rabbits. Braz J Otorhinolaryngol. 2007 Sep-Oct; 73(5): 627 31. doi: 10.1016/s1808-8694(15) 30122-1.

17. OECD Series on principles of good laboratory practice and compliance monitoring Number 20 Guidance Document for Receiving Authorities on the Review of the GLP Status of NonClinical Safety Studies. ENV/JM/MONO(2019)25. Доступно: http://www.oecd.org/officialdocuments/publicdispl aydocumentpdf/?cote=ENV-JM-

$\operatorname{MONO}(2019) 25 \% 20 \&$ doclanguage $=$ en .

18. Directive 2001/20/EC of the European Parliament and of the Council of 4 April 2001 on the approximation of the laws, regulations and administrative provisions of the member states relating to the implementation of good clinical practice in the conduct of clinical trials on medicinal products for human use. Med Etika Bioet. 2002 SpringSummer; 9(1-2): 12-9.

19. Islam MA, Al-Shiha A. Foundations of Biostatistics. Springer. 2018. 474 p.

20. Quirk T, Quirk MH, Horton HF. Excel 2016 for Biological and Life Sciences Statistics. Springer International Publishing: Switzerland; 2016. 


\title{
NASAL ENDOSCOPY PROSPECTSIN EXPERIMENTAL RHINOLOGY: SOME ASPECTS OF ENISAMIUM IODIDE NASAL SPRAY EFFECTIVENESSIN RHINOSINUSITIS
}

\author{
${ }^{1,2}$ Zhulai T, ${ }^{1}$ Zupanets I, ${ }^{1}$ Shebeko $S,{ }^{2}$ Yampolska K. \\ ${ }^{1}$ Department of Clinical Pharmacology and Clinical Pharmacy, \\ National University of Pharmacy, Kharkiv, Ukraine; \\ ${ }^{2}$ Non-profit Municipal Enterprise «City Clinical Hospital №30» of Kharkiv City Council, Kharkiv, Ukraine \\ e-mail:tszhulay2910@gmail.com \\ Abstract
}

Acute rhinosinusitis treatment and prevention is connected to the rational choice of drug dosage form, which will provide the therapeutic effect and the safety of a drug substance or a drug substance complex. Nasal spray with Enisamium Iodide can be used to nasal congestion relief in acute rhinosinusitis because the active substance has an anti-exudative action. Nasal endoscopy could be used in experimental rhinology as a method for direct pathology visualization and for evaluation of the effectiveness of test drugs.

Aim: To substantiate Enisamium Iodide (nasal spray) $10 \mathrm{mg} / \mathrm{mL}$ effectiveness on maxillary sinus ostium via nasal endoscopy in rabbits with experimental rhinosinusitis.

Methods: As a test object was used Enisamium Iodide (nasal spray). As a reference drug, we used BNO101. Experimental rhinosinusitis was induced in the $1^{\text {st }}$ day. On the $1^{\text {st }}, 15^{\text {th }}$ and $25^{\text {th }}$ days in all groups (four groups, six rabbits in each group), we used nasal endoscopy and semi-quantitative assessment to the result objectivity.

Results: The total score in the intact control group was $0(0 \div 0)$ on the $15^{\text {th }}$ and $25^{\text {th }}$ days (physiological state). The total score in the control pathology group was $2.0(2.0 \div 2.0)$ and $2.0(1.0 \div 2.0)$ (severe rhinosinusitis) respectively. The total score in Enisamium Iodide treated group was $2.0(1.0 \div 2.0)$ (severe rhinosinusitis) and 0.0 $(0.0 \div 1.0)$ (physiological state). The total score in BNO-101 treated group was $2.0(1.0 \div 2.0)$ (severe rhinosinusitis) and $1.0(1.0 \div 1.0)$ (mild rhinosinusitis).

Conclusions: Nasal endoscopy can be used as an informative visual method. Enisamium Iodide (nasal spray) has been shown a positive effect by endoscopic evaluation of maxillary sinus ostium and exceeded activity of the reference drug.

Keywords: experimental rhinosinusitis, maxillary sinus ostium, nasal endoscopy, Enisamium Iodide (nasal spray), effectiveness. 


\title{
ПЕРСПЕКТИВИ НАЗАЛЬНОЇ ЕНДОСКОПЇ̈ В ЕКСПЕРИМЕНТАЛЬНІЙ РИНОЛОГІї: ДЕЯКІ АСПЕКТИ ЕФЕКТИВНОСТІ ЕНІСАМІУМА ЙОДИДА НАЗАЛЬНОГО СПРЕЯ ПРИ РИНОСИНУСИТІ
}

\author{
${ }^{1,2}$ Жулай ТС, ${ }^{1}$ Зупанець IА, ${ }^{1}$ Шебеко СК, ${ }^{2}$ Ямпольська КС. \\ ${ }^{1}$ Національний фармацевтичний університет, кафедра клінічної фармакологї та клінічної фармації, \\ Харків, Україна; \\ ${ }^{2}$ Комунальне некомериійне підприємство «Міська клінічна лікарня №30» \\ Харківської міської ради, Харків, Украӥна \\ e-mail:tszhulay2910@gmail.com \\ Анотаиія
}

Лікування і профілактика гострого риносинуситу пов'язано з раціональним вибором лікарської форми, яка забезпечить терапевтичний ефект і безпеку використання лікарської речовини або комплексу лікарського речовини. Енісаміум Йодид (назальний спрей) може використовуватися для зменшення закладеності носа при гострому риносинуситі, тому що діюча речовина володіє антиексудативну дію. Назальна ендоскопія може бути використана в експериментальній ринологии як метод прямої візуалізації патології та для оцінки ефективності лікування досліджуваними препаратами.

Mema: Обгрунтувати ефективність Енісаміума Йодиду (назальний спрей) 10 мг/мл по відношенню до динаміки стану співустя верхньощелепної пазухи носа за допомогою назальної ендоскопії у кролів 3 експериментальним риносинуситом.

Memoдu: Як об'єкт дослідження був використаний Енісаміум Йодид (назальний спрей). У якості референтного препарату використовували БНО-101. Експериментальний риносинусит був індукований на 1-у добу. На 1-у, 15-у і 25-у добу у всіх групах (4 групи, по 6 тварин в кожній групі) застосовувалась назальна ендоскопія і напівкількісна оцінка для об'єктивізації результатів.

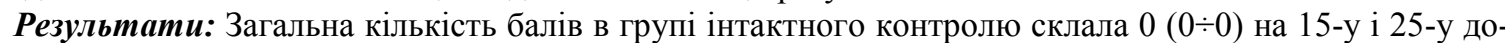
бу (фізіологічний стан). Загальна кількість балів в групі контрольної патології склала 2,0 $(2,0 \div 2,0)$ і 2,0 $(1,0 \div 2,0)$ (тяжкий перебіг риносинуситу), відповідно. Загальна кількість балів в групі, що одержувала Ені-

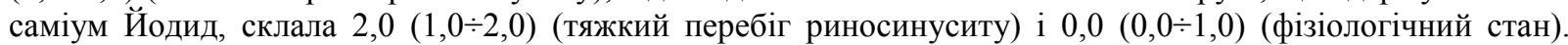
Загальна кількість балів в групі, що одержувала ВNO-101, склала 2,0 $(1,0 \div 2,0)$ (тяжкий перебіг риносинуситу) і $1,0(1,0 \div 1,0)$ (легкий перебіг риносинуситу).

Висновки: Назальна ендоскопія може бути використана в якості інформативного візуального методу. Енісаміум Йодид (назальний спрей) показав позитивний ефект на зміну стану співустя верхньощелепної пазухи, що підтверджено результатами назальної ендоскопії, і перевищив активність референтного препарату.

Ключові слова: експериментальний риносинусит, співустя верхньощелепної пазухи, назальна ендоскопія, Енісаміум Йодид (назальний спрей), ефективність 